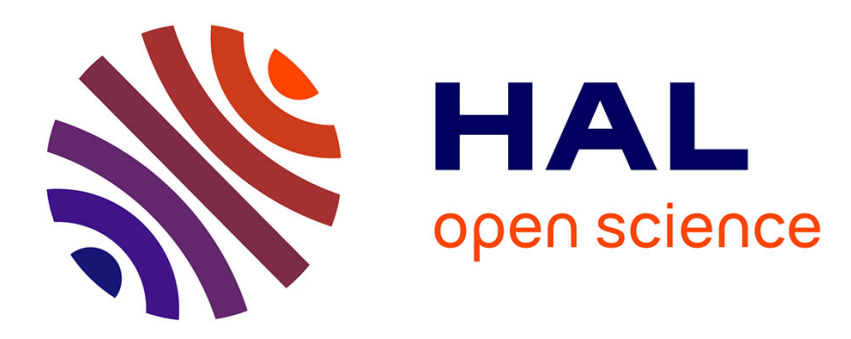

\title{
Improvement cross-breeding of Hungarian Merinos for increased prolificacy and milk yield
}

\author{
L. Veress
}

\section{To cite this version:}

L. Veress. Improvement cross-breeding of Hungarian Merinos for increased prolificacy and milk yield. Annales de génétique et de sélection animale, 1982, 14 (4), pp.580-580. hal-00893535

\section{HAL Id: hal-00893535 \\ https://hal.science/hal-00893535}

Submitted on 1 Jan 1982

HAL is a multi-disciplinary open access archive for the deposit and dissemination of scientific research documents, whether they are published or not. The documents may come from teaching and research institutions in France or abroad, or from public or private research centers.
L'archive ouverte pluridisciplinaire HAL, est destinée au dépôt et à la diffusion de documents scientifiques de niveau recherche, publiés ou non, émanant des établissements d'enseignement et de recherche français ou étrangers, des laboratoires publics ou privés. 


\title{
Improvement cross-breeding of Hungarian Merinos for increased prolificacy and milk yield
}

\author{
L. VERESS \\ Agricultural University of Debrecen, P.O. Box 36, 4015 Debrecen, Hungary
}

\begin{abstract}
Hungarian Merinos have been modernized in two ways of improvement cross-breeding. "Prolific Merino" is a new genotype containing 25 p. 100 Romanov, while "Modernized Merino" is one containing 50 p. 100 Australian "Booroola * Merino. Both breeds are expected to produce wool of the same quality as Merinos $(60-64$ s) but of longer staple. They are expected to gain weight more quickly, have oestrus and be able to conceive all the year round, be more prolific, have higher milk yields and be more persistent than the control group consisting of $\mathrm{Hun}$ garian Merinos. When comparing the results achieved by 430 "Prolific Merino" ewes with those of Hungarian Merinos kept on the same farm for control, it was found that the lambling rate of the former was 3-18 p. 100 higher, their prolificacy increased by $11-17$ p. 100 , their productivity rose by 11-35 p. 100 but the raw wool yield of the ewes was 1-8 p. 100 less. The weight gain of suckling lambs increased by 10-28 p. 100 compared by to the control group.
\end{abstract}

SESSION V

(Commune avec la Commission de Production bovine)

STRATÉGIES D'ÉLEVAGE EN PRODUCTION BOVINE

\section{Development of synthetic cattle populations}

\author{
K. HAMMOND \\ Animal Genetics and Breeding Unit, University of New England, \\ Armidale, 235l, Australia
}

\begin{abstract}
Open synthetics can have important advantages over other breeding strategies for utilising genotypic variation in cattle. They are particularly relevant where several exotic populations having similar or superior genetic means to the native population are available and where intense selection is possible when choosing immigrants. The immediate and longer-term gains can be greater than if selection was conducted in the native population alone and an open synthetic will be simpler to operate than systematic crossing strategies. The opportunity also exists to increase selection intensity without inbreeding problems. In addition, open synthetics can help overcome current deficiencies in our knowledge of "differences in means " and of "covariance structures " between populations and their crosses. Useful preliminary information on these deficiencies could be obtained by merging data banks exist in various countries and conducting the appropriate analyses.
\end{abstract}

